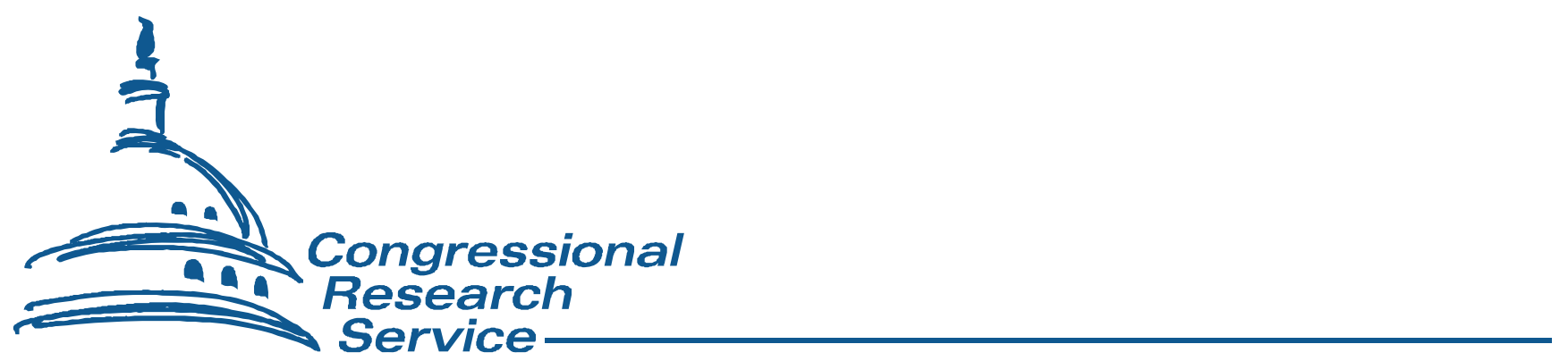

\title{
Metropolitan Transportation Planning
}

\author{
William J. Mallett \\ Specialist in Transportation Policy
}

February 3, 2010 


\section{Summary}

Federal law requires state and local governments to designate a metropolitan planning organization (MPO) in each urbanized area with a population of 50,000 or more to help plan surface transportation infrastructure and services. There are currently 381 MPOs nationwide. Despite some strengthening of their authority over the years, MPOs have generally remained subordinate to state departments of transportation (DOTs) in the planning and selecting ("programming") of projects using federal surface transportation funds. Moreover, it can be argued that at the metropolitan level MPOs are subordinate to local governments that own and operate many elements of the transportation system, and also control land use planning and zoning.

Because of the perceived weakness of MPOs, some in the transportation community have argued that they ought to be given much more power over the planning and programming of projects using federal surface transportation funds. Some of these observers go so far as to suggest that federal policies and programs in a number of areas, including transportation, housing, and the environment, need to be coordinated on a metropolitan scale, and that MPOs are the organizational venue where this should occur. Others argue that the relationship between state government, local government, and MPOs is well-balanced and should not be changed. A third view is that metropolitan transportation planning is controlled by planners who often harbor anticar views, and consequently, MPOs can be actually detrimental to well-functioning metropolitan transportation systems. In this view, MPOs should be abolished or, at the very least, have their functions significantly curtailed.

Surface transportation programs were authorized under the Safe, Accountable, Flexible, Efficient Transportation Equity Act: A Legacy for Users (SAFETEA-LU or SAFETEA) (P.L. 109-59) covering the period FY2005 through FY2009. In lieu of a new multi-year reauthorization that is still being considered, Congress has extended these programs and their funding several times. Reauthorization of the surface transportation programs provides an opportunity for Congress to reexamine policies related to MPOs and the metropolitan planning process. This report discusses several issues that Congress may want to consider: the authority of MPOs to plan and program funds; representation and participation in MPOs; MPO funding and technical capacity; and implementation of livability initiatives. It may also want to consider a number of issues having to do with planning requirements such as the need for a long-range plan, the proper scale of planning, and the incorporation of freight transportation interests. The report begins with a brief description of the metropolitan transportation planning process. 


\section{Contents}

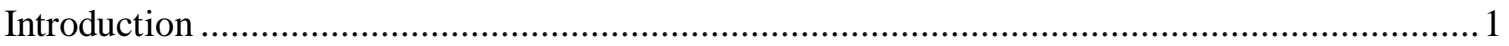

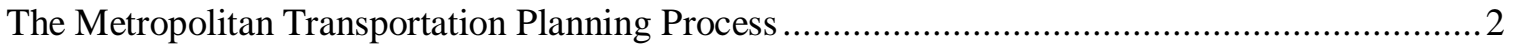

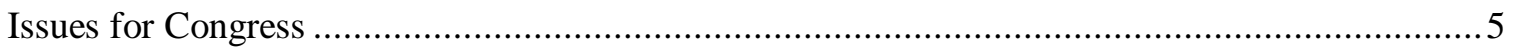

Decision-Making Authority of MPOs Relative to State DOTs............................................6

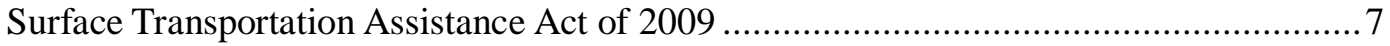

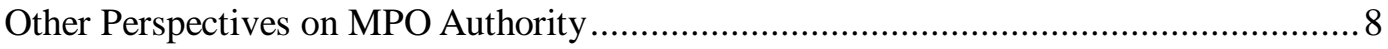

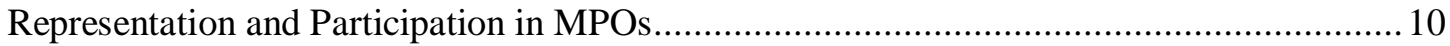

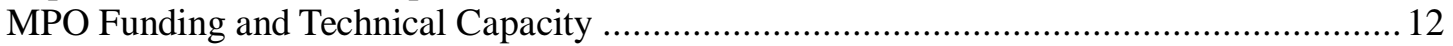

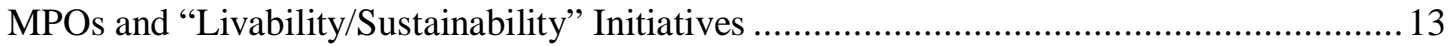

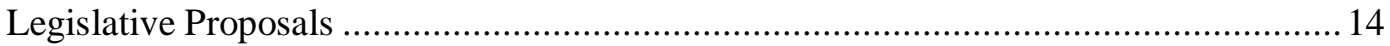

Climate Change Mitigation, Compact Cities, and Transportation ................................. 16

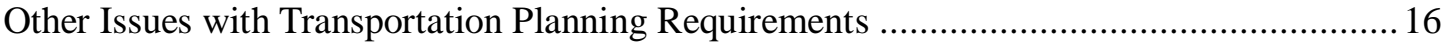

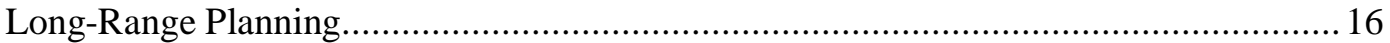

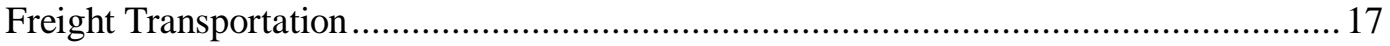

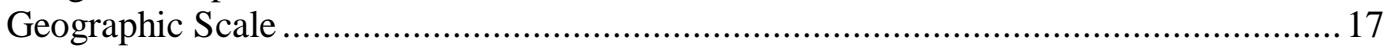

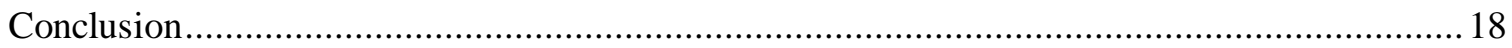

\section{Figures}

Figure 1. Federal Funds Apportioned for Metropolitan Transportation Planning,

FY2000-FY2009

\section{Contacts}

Author Contact Information 


\section{Introduction}

Since the early 1970s, federal law has required state and local governments to designate metropolitan planning organizations (MPOs) in urbanized areas with a population of 50,000 or more to help plan surface transportation infrastructure and services. ${ }^{1}$ There are currently 381 MPOs nationwide, of which 43 represent areas of 1 million residents or more (large MPOs), 139 represent areas of between 200,000 and 1 million (medium MPOs), and 199 represent areas of between 50,000 and 200,000 (small MPOs). ${ }^{2}$ The foremost rationale for MPOs and metropolitan transportation planning is that the metropolitan scale is the level at which most economic activities, including commuting and, therefore, local highway and transit systems, are organized. ${ }^{3}$ These "metropolitan economies" transcend local government and sometimes state boundaries, and, as some observers have argued, are often too far removed from state capitals for state governments to successfully oversee them. This is particularly an issue in places where a metropolitan area is spread over more than one state.

Despite some strengthening of their authority over the years, MPOs have generally remained subordinate to state departments of transportation (DOTs) in the planning and selecting ("programming") of projects using federal surface transportation funds. Moreover, it can be argued that at the metropolitan level MPOs are subordinate to local governments that own and operate many elements of the transportation system, and also control land use planning and zoning. ${ }^{4}$ Because of this perceived weakness, some in the transportation community have argued that MPOs ought to be given much more power over the planning and programming of projects using federal surface transportation funds. Some even go so far as to suggest that federal policies and programs in a number of areas, including transportation, housing, and the environment, need to be coordinated at the metropolitan scale, and that MPOs are the organizational venue where this should occur. Others argue that the relationship between state government, local government, and MPOs is well-balanced and should not be changed. A third view is that metropolitan transportation planning is controlled by planners who often harbor anti-car views, and, consequently, MPOs can be actually detrimental to well-functioning metropolitan transportation systems. In this view, MPOs should be abolished or, at the very least, have their functions significantly curtailed. ${ }^{5}$

\footnotetext{
${ }^{1}$ An urbanized area is defined as consisting of "contiguous, densely settled census block groups and census blocks that meet minimum population density requirements, along with adjacent densely settled census blocks that together encompass a population of at least 50,000 people." U.S. Department of Commerce, Bureau of the Census, "Urban Area Criteria for Census 2000," 69 Federal Register 51, pp. 11663-11670. Metropolitan (statistical) areas are county-based geographical units that typically include a large, densely settled central county together with surrounding counties that are functionally linked with the core county as defined by commuting patterns. Consequently, unlike an urbanized area, a metropolitan statistical area will typically encompass both urban and rural land within its borders. See Office of Management and Budget, "Standards for Defining Metropolitan and Micropolitan Statistical Areas," 65 Federal Register 249, pp. 82228-82238.

${ }^{2}$ U.S. Government Accountability Office, Metropolitan Planning Organizations: Options Exist to Enhance Transportation Planning Capacity and Federal Oversight, GAO-09-868, September 2009, http://www.gao.gov/ new.items/d09868.pdf.

${ }^{3}$ Peter Calthorpe and William Fulton, The Regional City: Planning for the End of Sprawl (Washington, DC: Island Press, 2001).

${ }^{4}$ Genevieve Giuliano, “Where Is the 'Region’ In Regional Transportation Planning?," in Up Against the Sprawl, ed. Jennifer Wolch, Manuel Pastor, Jr., Peter Dreier (Minneapolis: University of Minnesota Press, 2004).

${ }^{5}$ See, for example, Randal O'Toole, "Roadmap to Gridlock: The Failure of Long-Range Metropolitan Transportation Planning," Cato Institute, Policy Analysis, no. 617 (May 27, 2008), http://www.cato.org/pubs/pas/pa-617.pdf.
} 
For the period FY2005 though FY2009, surface transportation programs were authorized by the Safe, Accountable, Flexible, Efficient Transportation Equity Act: A Legacy for Users (SAFETEA; P.L. 109-59). In lieu of a new multi-year reauthorization that is still being considered, Congress has extended these programs and their funding several times. Reauthorization of the surface transportation programs provides an opportunity for Congress to reexamine policies related to MPOs and the metropolitan planning process. ${ }^{6}$ Changes are also being considered as part of climate change legislation. This report discusses several issues that Congress may want to consider: the authority of MPOs to plan and program funds; representation and participation in MPOs; MPO technical capacity; and implementation of livability/sustainability initiatives. It also considers a number of other planning issues including the requirements for a long-range plan, the proper scale of planning, and the incorporation of freight transportation needs. These issues are discussed in detail below after a brief description of the metropolitan transportation planning process.

\section{The Metropolitan Transportation Planning Process}

The federal requirement for transportation planning in urban areas, although not MPOs, dates to the Federal-Aid Highway Act of 1962 (P.L. 87-866), which called for "a continuing comprehensive transportation planning process carried on cooperatively by states and local communities." MPOs themselves have been required as part of the transportation planning process in urbanized areas since the enactment of the Federal-Aid Highway Act of 1973 (P.L. 9387) (23 U.S.C. §134; 49 U.S.C. §5303). In general, the designation of the MPO, the design of its organizational structure, and voting representation within the MPO are to be agreed upon by the governor of the state and the general-purpose local governments of the area. In urbanized areas of 200,000 residents or more, designated as transportation management areas (TMAs), federal law requires that the MPO must consist of local elected officials, officials from public agencies that operate major modes of transportation (transit agencies, port authorities, etc.), and appropriate state officials (23 U.S.C. §134(d)(2); 49 U.S.C. §5303(d)(2)). Typically, these officials form a policy board in which some members have voting rights and others do not. Day-to-day operations of an MPO are usually managed by an executive director appointed by the board, and a staff composed largely of professional planners. The number of staff supporting the work of the MPO is typically very small. The Government Accountability Office (GAO) recently found the average (mean) number of full-time and part-time staff working for small MPOs was 3.2 and 1.4, respectively. For medium MPOs the averages were 8.2 full time and 1.5 part time staff, and for large MPOs the averages were 49.3 full time and 3.9 part time. ${ }^{8}$ With few permanent staff, smaller MPOs often hire consultants to do technical work, rely on help from the state DOT, or both.

The two major requirements of every MPO are the preparation of a long-range, multi-modal Metropolitan Transportation Plan (MTP) covering a minimum period of 20 years, and a Transportation Improvement Program (TIP) covering four years. The MTP must be updated at least every five years, or four years in areas with air quality problems, and the TIP must be updated at least every four years. The MTP is required to include an assessment of transportation

\footnotetext{
${ }^{6}$ CRS Report R40780, Surface Transportation Reauthorization Legislation in the $111^{\text {th }}$ Congress: Summary of Selected Major Provisions, coordinated by John W. Fischer.

${ }^{7}$ P.L. 87-866, Section 134.

${ }^{8}$ GAO, 2009, p. 12.
} 
supply and demand in the metropolitan area; operational and infrastructure investment strategies to improve the condition and performance of the system; estimates of transportation's effects on environmental quality and how these effects can be mitigated; and a financial plan that shows how the MTP can be implemented. Two important components of developing the long-range plan are preparation of travel demand forecasts and estimates of other inputs and outputs such as future land use patterns and pollutant emissions. ${ }^{9}$

The four-year TIP is a priority list of proposed federally supported highway and transit projects and strategies. Federal law requires that the list of projects and strategies must be "fiscally constrained" in that the program must be supported by reasonable estimates of available funding. To put it another way, the TIP must include a priority list of projects and strategies over the coming four years that have a reasonable chance of being accomplished with available funding. The TIP must be approved by both the MPO and the governor (although the actual approval is often delegated to the state DOT), and be consistent with the MTP. Federally supported projects must be selected from the approved TIP. Large and medium MPOs, those in urbanized areas of 200,000 residents or more, have the authority to select projects from the TIP in consultation with the state and public transit operators, except projects carried out on the National Highway System (NHS), or under the Bridge Program and Interstate Maintenance (IM) Program. In those cases, the state DOT has the authority to select projects from the TIP in cooperation with the MPO. MPOs in small urban areas, however, have less authority than those in larger areas. This is because power to select highway projects from the TIP is given to the state and power to select transit projects is given to the designated recipients of public transit funding. Project selection by the state or transit system, however, must be done in cooperation with the MPO, a stronger requirement than consultation.

The transportation plans of a metropolitan area must be consistent with transportation plans that are required at the state level. Moreover, in metropolitan areas that are in nonattainment or maintenance status for air quality, ${ }^{10}$ transportation plans must be in conformity with the state implementation plan (SIP) required to bring the area into compliance with air pollution standards. ${ }^{11}$ The local MPO policy board is responsible for making a conformity determination between the regional transportation plan and regional air quality plan. This determination must be made at least every four years, when a MTP or TIP is updated or amended, or within 24 months after a SIP or SIP revision is approved by the Environmental Protection Agency. ${ }^{12}$

Some argue that development of the TIP, also known as project "programming," is the most important activity of an MPO because it provides the potential for setting budgetary priorities. ${ }^{13}$

\footnotetext{
${ }^{9}$ U.S. Department of Transportation, Federal Highway Administration, Federal Transit Administration, The Transportation Planning Process: Key Issues, FHWA-HEP-07-039, Washington, DC, 2007, http://www.planning.dot.gov/documents/briefingbook/bbook_07.pdf.

${ }^{10}$ A nonattainment area is an area designated by the Environmental Protection Agency under the Clean Air Act (CAA) as not meeting the national primary or secondary ambient air quality standards for one or more designated pollutants. A maintenance area is an area that was previously designated nonattainment and subsequently redesignated to attainment subject to the development of a maintenance plan required under the CAA.

${ }^{11}$ For more information, see CRS Report RL32106, Transportation Conformity Under the Clean Air Act: In Need of Reform?, by James E. McCarthy.

${ }^{12}$ U.S. Department of Transportation, The Transportation Planning Process: Key Issues, 2007.

${ }^{13}$ Paul G. Lewis and Mary Sprague, Federal Transportation Policy and the Role of Metropolitan Planning Organizations in California, Public Policy Institute of California, San Francisco, CA, April 1997, p. 8, http://www.ppic.org/content/pubs/report/R_497PLR.pdf.
} 
Prior to enactment of the Intermodal Surface Transportation Efficiency Act of 1991 (ISTEA; P.L. 102-240), a TIP did not need to be fiscally constrained, thus, a common complaint was that such documents were long "wish lists" from which the state could choose the projects to fund. By contrast, since ISTEA, MPOs, particularly those in areas designated as TMAs, have had a say in developing the TIP and in selecting projects from the TIP to be implemented. Moreover, ISTEA is also said to have empowered MPOs by giving them primary authority over Surface Transportation Program (STP) funds designated for projects in specific urban areas, so-called "suballocated" funds, and, to a lesser extent, authority over Congestion Mitigation and Air Quality Improvement Program (CMAQ) funds.

The planning area for which the MPO is generally responsible is the urbanized area and the area likely to become urbanized over the next 20 years, and may, therefore, encompass the entire metropolitan statistical area. ${ }^{14}$ The planning process is required to be multi-modal, and is to include consideration of a range of factors: economic competitiveness; safety; security; accessibility and mobility of people and freight; environmental quality, energy conservation, quality of life, and consistency with growth and economic development patterns; intermodal connectivity; efficient management and operation of the system; and preservation of the existing system (23 U.S.C. §134(h)(1); 49 U.S.C. §5303(h)(1)). In areas designated as TMAs, planning must include a congestion management process that encompasses travel demand reduction and operational management strategies (23 U.S.C. \$134(k)(3); 49 U.S.C. \$5303(k)(3)). ${ }^{15} \mathrm{In}$ nonattainment areas "federal funds may not be advanced ... for any highway project that will result in a significant increase in the carrying capacity for single-occupant vehicles unless the project is addressed through a congestion management process" (23 U.S.C. $\$ 134(\mathrm{~m})(1) ; 49$ U.S.C. $§ 5303(\mathrm{~m})(1))$.

The metropolitan planning process, in areas designated as TMAs, must be certified by the Secretary of Transportation as being carried out according to federal law. Working together, FHWA and FTA perform certification reviews. Certification is required not less often than once every four years. Certification is based on the way in which the planning is carried out, not the success or failure of the projects and strategies ultimately employed. Among other things, a certification review will examine the participation of interested parties in the planning process. Federal law requires that at a minimum, stakeholders, including freight shippers, public transit operators, and the general public, be given reasonable opportunity to comment on the transportation plan. To that end, MPOs are required to develop a public participation plan. If federal certification is not granted, the Secretary may withhold $20 \%$ of highway and transit project funds attributable to the area.

In addition to the activities prescribed by federal law, some MPOs carry out other activities that may by given to them by state or local government. These include land-use planning, project implementation, transit operations, and environmental planning in addition to air quality

\footnotetext{
${ }^{14}$ As noted earlier, metropolitan statistical areas are county-based geographical units that typically comprise a large, densely settled central county and the surrounding counties that are functionally linked with the core county as defined by commuting patterns. Consequently, unlike an urbanized area, a metropolitan statistical area will typically encompass both urban and rural land within its borders.

${ }^{15}$ Travel demand reduction strategies include incentives to ride public transit, carpool, and work at home. Operational management strategies can include incident management, transit priority, and traveler information, among others. For more information, see U.S. Department of Transportation, Federal Highway Administration, An Interim Guidebook on the Congestion Management Process in Metropolitan Transportation Planning, FHWA-HOP-08-008, Washington, DC, February 2008, http://www.ops.fhwa.dot.gov/publications/cmpguidebook/cmpguidebook.pdf.
} 
emissions analysis. According to GAO, $70 \%$ of MPOs have some land use planning responsibilities, $37 \%$ implement projects, $21 \%$ do additional environmental planning such as water quality planning, and $16 \%$ operate transit service. ${ }^{16}$

Although metropolitan transportation planning and MPOs are supported with resources from federal, state, and local government, federal funding typically provides a majority of that support. About $80 \%$ of MPOs get a majority of planning funds from the federal government. ${ }^{17}$ Federal funding for metropolitan transportation planning is predominantly provided through a $1.25 \%$ deduction of federal highway funding authorized for five highway programs: IM, NHS, Bridge, STP, and CMAQ. These deducted funds are apportioned to each state as metropolitan planning funds based primarily on the ratio of urbanized population in a state to the total urbanized population, although every state receives at least $0.5 \%$ of the total nationwide apportionment. Federal metropolitan planning funds apportioned to a state are distributed to individual MPOs based on a formula developed by the state in consultation with the MPOs and approved by FHWA. In addition to planning funds apportioned in this way, NHS, STP, and Equity Bonus (EB) funds may be used for planning activities. Federal transit funds are also available for metropolitan planning (Section 5303 funds). MPOs are required to match federal funds with $20 \%$ of funds from state and local sources. For FY2009, nearly $\$ 400$ million in federal funds were apportioned for metropolitan planning, with about $\$ 304$ million from federal highway funds and \$94 million from federal transit funds. Federal funds apportioned for metropolitan transportation planning since 2000 can be seen in Figure 1.

\section{Issues for Congress}

Since the first federal requirements for urban transportation planning in the early 1960s and for MPOs in the early 1970s, Congress has modified and generally strengthened the metropolitan transportation planning process and the role of MPOs. Arguably, the biggest changes date to the enactment of the ISTEA and the requirements of the Clean Air Act Amendments of 1990 (CAAA; P.L. 101-549). Among other changes, ISTEA brought in the requirements for a fiscally constrained TIP, suballocated funds to urbanized areas, funding to air quality non-attainment and maintenance areas through CMAQ, and, in concert with the CAAA, made air quality an important goal of metropolitan planning. ISTEA also increased the amount of federal planning funds provided to MPOs. Subsequent surface transportation reauthorization legislation, the Transportation Equity Act for the $21^{\text {st }}$ Century, as amended, enacted in 1998 (TEA-21; P.L. 105178; P.L. 105-206) and SAFETEA, enacted in 2005, reaffirmed these changes with some modifications.

With the initial expiration of SAFETEA at the end of FY2009, the role of MPOs is once again being debated in Congress in the context of reauthorizing the federal surface transportation programs. There appear to be five major issues that Congress may consider in this debate: (1) the authority of MPOs relative to state DOTs to plan and program funds; (2) representation and participation in MPOs; (3) MPO funding and technical capacity; (4) MPOs and the implementation of livability/sustainability initiatives; and (5) other issues with transportation planning requirements.

${ }^{16}$ GAO, 2009, pp. 13-15.

${ }^{17}$ Ibid., p. 12. 


\section{Figure I. Federal Funds Apportioned for Metropolitan Transportation Planning, FY2000-FY2009}

(\$ Millions)

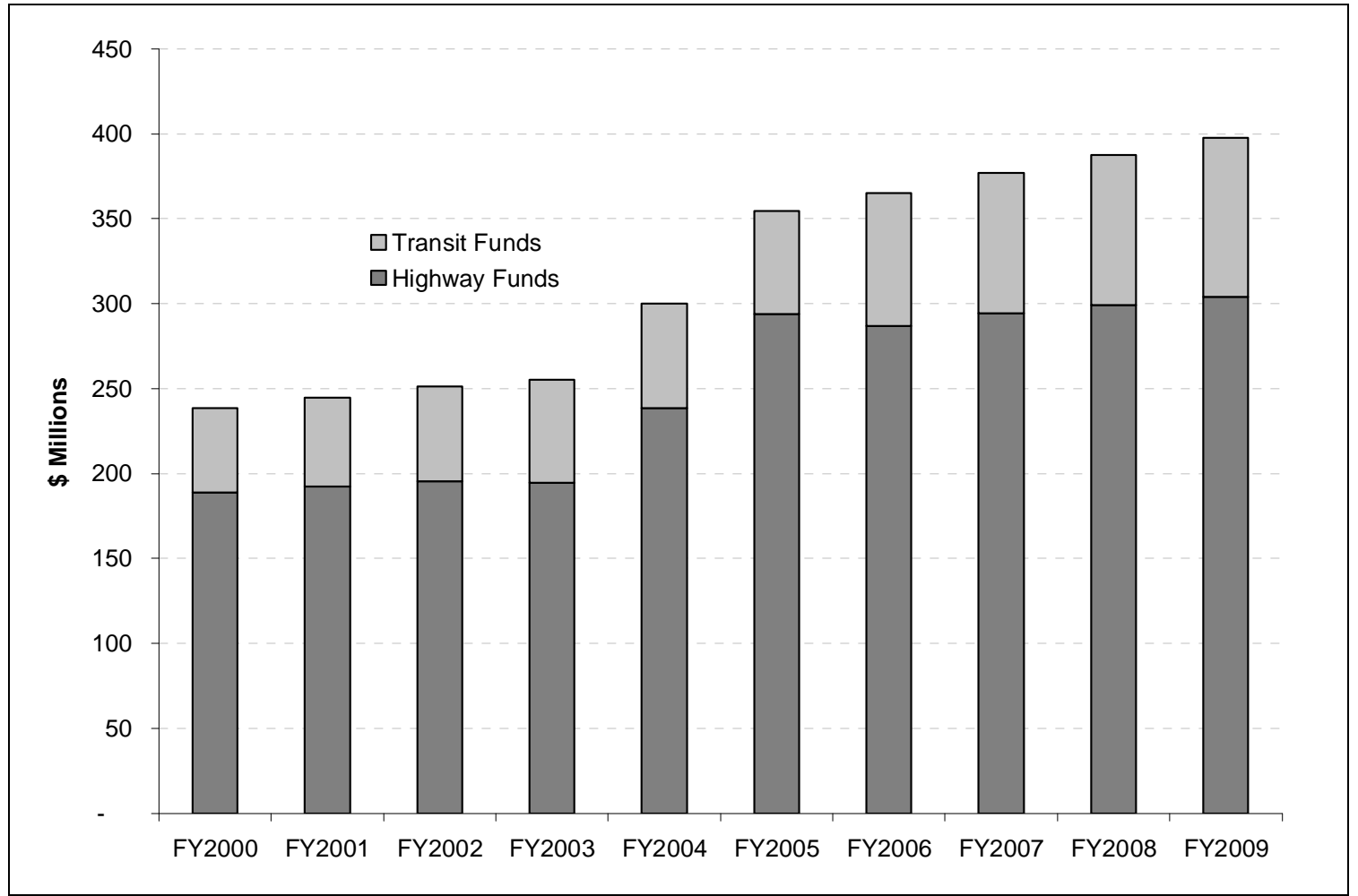

Source: U.S. Department of Transportation, Federal Highway Administration and Federal Transit Administration.

\section{Decision-Making Authority of MPOs Relative to State DOTs}

Possibly the most important issue for Congress with respect to metropolitan transportation planning is the decision-making authority of MPOs, particularly with respect to the authority of state DOTs, and the effect this has on the geography of infrastructure funding. One prominent view on this issue is that under current law MPOs are relatively powerless because most federal highway funding is controlled by the states. Because many state legislatures and state DOTs have historically been dominated by rural areas, it has been argued that, consequently, urban regions have generally fared relatively poorly in highway funding. ${ }^{18}$ As one transportation coalition has asserted, a "reason to increase the decisionmaking authority and ability of MPOs is that many states continue to penalize metropolitan areas in the distribution of transportation funds." 19 Moreover, adherents to this view suggest that even with money that is directed to urban areas, the authority of MPOs is weak because project selection by MPOs must be done in cooperation or

\footnotetext{
${ }^{18}$ Robert Puentes and Linda Bailey, "Increasing Funding and Accountability for Metropolitan Transportation Decisions," and Edward Hill et al., "Slanted Pavement: How Ohio's Highway Spending Shortchanges Cities and Suburbs," in Bruce Katz and Robert Puentes, eds., Taking the High Road: A Metropolitan Agenda for Transportation Reform, Washington, DC, Brookings Institution Press, 2005.

${ }^{19}$ Transportation for America, The Route to Reform: Blueprint For a $21^{\text {st }}$ Century Federal Transportation Program, Washington, DC, 2009, p.153 (emphasis in original), http://t4america.org/docs/blueprint_full.pdf.
} 
consultation with the state DOT and local governments. Indeed, when local control exists it still tends to rest with local jurisdictions that are often more interested in receiving their "fair share" of project money than on solving regional transportation problems. ${ }^{20}$

Another effect of state DOTs being largely in control of highway funding, these observers argue, is a bias towards highway construction projects of a type that is more suited to rural environments. Adherents to this view contend that highway improvements tend to be of the larger kind that accommodate faster speeds, and, thus, are not built with non-vehicular traffic in mind. Consequently, it is said, there has been much less emphasis on transportation improvements that might be better suited to urban environments, including roads with slower design speeds that accommodate bicyclists and pedestrians, operations and management improvements such as signal timing, and the use of "highway" funds on other modes such as transit. This alleged spending bias has implications for urban development because, as one think-tank put it, "state DOT's traditional focus on highway maintenance and construction fosters metropolitan decentralization that negatively impacts cities and older suburbs." ${ }^{21}$

According to this view, more federal funding needs to be directed to urbanized areas, and greater power to make infrastructure funding decisions needs to be placed in the hands of MPOs. Providing this greater authority is often linked to requiring greater accountability for transportation outcomes. One coalition of transportation groups argues for "empowering regions to shape their future by giving them more direct funding and decision-making authority, while holding them accountable for results." 22

\section{Surface Transportation Assistance Act of 2009}

Some of these ideas are contained in the proposed Surface Transportation Assistance Act of 2009 (STAA), a bill that has not been formally introduced and, hence, is unnumbered, but nonetheless has been subject to markup by the House Committee on Transportation and Infrastructure, Subcommittee on Highways and Transit. ${ }^{23}$ Although the bill is incomplete, lacking funding data and other details on several of what might be the most significant features in the bill, there are a number of legislative proposals pertaining to MPOs. STAA creates the Metropolitan Mobility and Access (MMA) Program which would provide funding and financing authority directly to MPOs in areas of 500,000 or more. ${ }^{24}$ According to the draft bill:

The purpose of the metropolitan mobility and access program shall be to provide multimodal transportation funding and financing authority directly to metropolitan planning organizations, thereby allowing MPOs broad multi-modal flexibility in planning and implementing programs of surface transportation projects to reduce vehicular congestion, to

\footnotetext{
${ }^{20}$ Downs, Anthony and Robert Puentes, "The Need for Regional Anticongestion Policies," in Katz and Puentes, 2005.

${ }^{21}$ Brookings Institution, A Bridge to Somewhere: Rethinking American Transportation for the $21^{\text {st }}$ Century, Washington, DC, 2008, p. 153, http://www.brookings.edu/ /media/Files/rc/reports/2008/06_transportation_puentes/ 06_transportation_puentes_report.pdf.

${ }^{22}$ Transportation for America, 2009, p.11.

${ }^{23}$ CRS Report R40780, Surface Transportation Reauthorization Legislation in the $111^{\text {th }}$ Congress: Summary of Selected Major Provisions, coordinated by John W. Fischer.

${ }^{24}$ Whether all MPOs are authorized under state and local laws to receive funds directly from the federal government is uncertain (See 23 U.S.C. Section 134).
} 
maximize mobility and access of people and goods, and to improve safety, environmental sustainability, and livability in large urbanized areas. ${ }^{25}$

To be eligible to receive funding, an MPO will have to develop a metropolitan mobility plan that is approved by DOT. The MMA requires an MPO to have an approved metropolitan mobility plan, supported by performance-based goals and metrics, to receive funds. Beginning in FY2012, continued funding is contingent on providing an annual report which documents progress toward the goals, reasons for failing to meet any of the goals, and a new plan by which the goals will be met going forward.

Providing federal highway funding directly to MPOs would be a major change in the way the Federal-Aid Highway Program operates, and could be a major shift in authority from the states to the MPOs. Apart from the question of the relative power of MPOs and state DOTs, there are some in the transportation community who worry about the ability of some MPOs, particularly those in small and medium size urbanized areas, to administer federal funds efficiently. Another concern, at least in some states, is that MPOs may not have the legal authority to receive federal funds directly. Although most MPOs are not officially units of government, but instead cooperative, intergovernmental organizations, the creation and organization of MPOs is, by and large, dictated by state law. Consequently, changes to funding mechanisms and the authority of MPOs at the federal level may require states and local governments to reevaluate MPO governance structures.

\section{Other Perspectives on MPO Authority}

Putting the intergovernmental question aside, the case can be made that unless federal funding is very substantial and comes with much stronger authority over project implementation and other matters, such as land use, MPOs are likely to remain relatively weak. This is because real power will still be centered within state/local government, including single-mode entities such as transit agencies, and local officials that typically make up the governing board of an MPO will find it hard to make decisions that while good for the region may be detrimental to the interests of their home jurisdiction. For example, a commission established by the State of Washington to examine transportation issues in the Puget Sound region found that there were 128 agencies managing some aspect of transportation in the four-county area. The commission noted that:

formal and informal discussions with over 100 individuals and more than 50 agencies reveal the difficulties that these individuals and agencies face when attempting to prioritize regional interests in transportation infrastructure. These officials bring hard work, intelligence and insight to their roles. However, they are charged with advancing the interests of an individual agency, district, city, county or the state as a whole, or with protecting the interests of a particular mode of transportation, such as roads or transit. ${ }^{26}$

It recommended, therefore, that:

the [Washington State] Legislature create a new 15-member Puget Sound Regional Transportation Commission (PSRTC) that has authority and responsibility for planning, prioritizing and funding all modes of regional transportation for the four-county area.... Our recommendations suggest that the agency should have responsibility for land use, roads and

\footnotetext{
${ }^{25}$ Surface Transportation Authorization Act of 2009, Section 1205, http://transportation.house.gov/Media/file/ Highways/HPP/OBERST_044_xml.pdf.

${ }^{26}$ Regional Transportation Commission, Final Report, December 31, 2006, pp. 5-1.
} 
transit, including the three current regional entities. We believe the agency should have taxing, tolling and borrowing authority. ${ }^{27}$

Although this recommendation, at least in terms of transportation planning, was repeated by the Washington State Auditor in a study of highway traffic congestion in the Puget Sound regionwith the additional thought that this single control could be given to either the Washington State DOT or a new regional entity-it is perhaps not surprising that such a powerful regional entity has not been established to date. ${ }^{28}$

An opposing view is that Congress should abolish federal involvement in metropolitan planning which deals with mostly local or regional concerns. ${ }^{29}$ In this view, metropolitan transportation planning and MPOs have largely failed, not because they are too weak, but because they are beholden to a special-interest coalition of government planners, private consultants, and others who favor behavioral "smart growth" strategies to deal with regional transportation problems such as highway congestion, air pollution, and greenhouse gas (GHG) emissions. Smart growth strategies, it is argued, rely on making urban areas more dense through land use regulation, and by placing greater funding emphasis on alternatives to cars and trucks such as transit, bicycling, and walking. According to this view, these behavioral tools failed in dealing with urban air quality problems, and they will fail to reduce GHG emissions, particularly if cost effectiveness is used as a criterion.

As a corollary to this view, the case can be made that while urban regions do relatively poorly in terms of highway funding, they more than make up for it in terms of transit funding that is typically provided directly to transit operators and is supported by highway user fees.

Additionally, it might be argued that highway funding tends to be directed to more rural parts of the state because there are great needs for intercity connectivity, even for urban residents, and it is at the rural fringes of urban regions where population growth tends to be fastest, and, hence, where infrastructure needs are greatest.

A third view is that Congress should make little or no change to the current authority of MPOs nor to the relationship between MPOs and state DOTs. This is the view of the American Association of State Highway and Transportation Officials (AASHTO), the association of state DOTs. In its view, the current process properly assigns authority to the owner of each element in the hierarchy of the highway system and requires a proper level of cooperation between different levels of government through the MPO. It argues that:

changes to this relationship risk a loss of state control over state-owned roads, including Interstate highways and National Highway System facilities, potentially allowing local concerns to dominate broader state and national transportation and economic needs such as freight movement through and around these urban areas. ${ }^{30}$

\footnotetext{
${ }^{27}$ Ibid., introductory letter to the governor, State Senate, and State House of Representatives.

${ }^{28}$ Washington State Auditor, Washington State Department of Transportation, Managing and Reducing Congestion in the Puget Sound, Performance Audit, Report No. 1000006, Olympia, WA, October 2007, http://www.sao.wa.gov/ auditreports/auditreportfiles/ar1000006.pdf.

${ }^{29}$ Randal O'Toole, 2008.

${ }^{30}$ American Association of State Highway and Transportation Officials (AASHTO), "AASHTO Authorization Policy, Topic IV: Project and Program Development and Delivery,” p. 35, http://www.transportation.org/sites/policy_docs/ docs/iv.pdf.
} 


\section{Representation and Participation in MPOs}

As noted earlier, the organizational structure of an MPO, including the make-up of the governing board and voting rights, and its decision-making processes (e.g., majority vote or consensus) are largely at the discretion of state and local lawmakers. Despite variation in the way MPOs are organized around the country, MPOs are typically governed by a board of voting members made up of local elected representatives selected from member jurisdictions. Other voting and nonvoting members may be appointed ex officio, such as the head of the local transit agency, or by gubernatorial appointment, such as a representative from the state DOT. Many MPOs have advisory committees that support the policy board, such as those dedicated to technical, freight, air quality, and bicycle/pedestrian issues, and many have a citizens advisory committee. ${ }^{31}$

Voting representation on MPO policy boards varies widely, but voting weighted by the population of member jurisdictions is relatively uncommon. ${ }^{32}$ Because the resident population of member jurisdictions is often vastly different, a common criticism is that this creates a serious problem of unequal representation, or malapportionment, on the MPO policy board. A number of studies have found that this malapportionment tends to over-represent suburban residents at the expense of central city residents, and that this geographical disparity also tends to result in an underrepresentation of racial and ethnic minorities in the decision-making of MPOs. ${ }^{33}$

One study of MPOs in the 50 largest urbanized areas found that only 16 provided for voting weighted by population. ${ }^{34}$ In five of the 16 , the weighting is proportional to population, but in the remaining 11 the weighting provides additional votes to the more populous jurisdictions, but not in proportion to population size. The study found that, on average, while central city populations make up 59\% of residents overseen by MPOs, they only receive $29 \%$ of votes on MPOs' boards. In contrast, suburban residents make-up $26 \%$ of the population, but receive $55 \%$ of the votes. The remaining $15 \%$ of votes go to non-local entities such as transit agencies and state DOTs. The study also showed that racial and ethnic minorities also tended to be underrepresented among MPO voting board members in part because of the geographical bias. While non-Hispanic white residents of the 50 urbanized areas studied were $61 \%$ of the population, $88 \%$ of the voting members on MPO boards were non-Hispanic white. Correspondingly, other groups were underrepresented: black 15\% population, $7 \%$ voting board members; Hispanic $17 \%$ population, $3 \%$ voting board members; Asian $6 \%$ population, $1 \%$ voting board members.

The effects of underrepresentation of central cities and racial and ethnic minorities in the composition of MPO voting boards are still not fully clear, but one research study has found a link between representation and the share of funding directed to transit. This study of 20 large

\footnotetext{
${ }^{31}$ Alexander Bond and Jeff Kramer, "Governance of Metropolitan Planning Organizations: Board Size, Composition, and Voting Rights," Paper presented at the Transportation Research Board annual meeting, Washington, DC, January 11,2010 .

${ }^{32}$ Ibid.

${ }^{33}$ Paul G. Lewis, "Regionalism and Representation: Measuring and Assessing Representation in Metropolitan Planning Organization," Urban Affairs Review, vol. 33, no. 6 (July 1998), pp. 839-853; Association of Metropolitan Planning Organizations, "AMPO Survey Results: Policy Board Structure,” at http://www.ampo.org/assets/ 62_policyboardstructure.doc; Thomas W. Sanchez, An Inherent Bias? Geographic and Racial-Ethnic Patterns of Metropolitan Planning Organization Boards, Brookings Institution, Washington, DC, January 2006, http://www.brookings.edu/ /media/Files/rc/reports/2006/01transportation_sanchez/20060124_mpos.pdf.

${ }^{34}$ Sanchez, 2006.
} 
MPOs found that for every extra vote suburban areas receive on an MPO board between $1 \%$ and $7 \%$ less funds were directed to transit in the MPO budget. ${ }^{35}$

Although malapportionment exists in many MPOs, an alternative view is that it does not have as much of an effect on decision-making as the research would seem to suggest. This is because a large number of MPOs work on a consensus basis, and, in MPOs where voting in proportion to population size is provided for, in practice it is rarely used. ${ }^{36}$ The case can be made that less than proportional representation prevents the most populous jurisdiction(s) in a metropolitan area from dominating the MPO. Less populous jurisdictions also can be geographically large or rapidly growing and, thus, it might also be argued, deserve more say than population alone would indicate.

Furthermore, it might be argued that MPO decisions with respect to minority and low-income populations are constrained by other federal laws and regulations including Title VI of the Civil Rights Act and Executive Order 12898 (Federal Actions to Address Environmental Justice in Minority Populations and Low-Income Populations). Based on Title VI requirements, an MPO must develop a public participation plan for "seeking out and considering the needs of those traditionally underserved by existing transportation systems, such as low-income and minority households, who face challenges accessing employment and other services" (23 CFR 450.318). As noted earlier, the metropolitan planning process, in areas designated as TMAs, must be certified by the Secretary of Transportation as being carried out according to federal law, and, thus, an MPO certification review is when compliance with these requirements can be enforced. But critics contend that withholding or providing conditional certification is a relatively weak way of enforcing participation requirements, and one rarely used. ${ }^{37}$ Also, these public participation requirements do not directly address the question of representation on the local MPO policy board. On the other hand it might be argued that many MPOs have made a legitimate attempt with limited resources to involve traditionally underserved communities, and that often it is difficult to generate involvement with seemingly arcane deliberations, far removed from the usual topics of interest to such communities.

If Congress believes it is desirable to alter local representation and participation in MPOs, there are a number of possible avenues that it might take. Congress could require that voting on MPO boards be in proportion to the population of the member jurisdictions. This approach is taken in the STAA. Another possibility is to strengthen the federal certification requirements for MPOs, especially those in TMAs, to take greater account of public participation, and to more formally consider voting and non-voting board membership, advisory committee membership, and voting mechanisms as possible sources of bias. ${ }^{38} \mathrm{~A}$ third suggestion is for MPOs to place greater emphasis on public participation, recruitment of minorities to serve on advisory committees, and the diversity of policy boards, including non-voting members. ${ }^{39}$ Congress might support this essentially state and local initiative by providing DOT with more funding to develop and share techniques, including leadership training, for achieving such ends.

\footnotetext{
${ }^{35}$ Arthur C. Nelson, Thomas W. Sanchez, and James F. Wolf, et al., "Metropolitan Planning Organization Voting Structure and Transit Investment Bias: Preliminary Analysis with Social Equity Implications," Transportation Research Record, vol. 1895 (2004), pp. 1-7.

${ }^{36}$ Association of Metropolitan Planning Organizations.

${ }^{37}$ Sanchez, 2006.

${ }^{38}$ Ibid.

${ }^{39}$ Ibid.
} 


\section{MPO Funding and Technical Capacity}

Another concern with MPOs is that most do not have the technical capacity, or the funding, to successfully fulfill federal planning requirements, including developing the long-range plan, the TIP, and conducting public meetings. As noted earlier, apart from a handful of MPOs in the largest areas, MPOs tend to have small executive and technical staffs, and many rely on staff time and expertise from other agencies, typically state DOTs. One specific problem is conducting the modeling that is required as the basis of forecasting future travel growth, capacity needs, and, in air quality non-attainment and maintenance areas, conformity with air quality plans. As the modeling requirements have become increasingly complex over time, many MPOs have had trouble keeping up. Additionally, many MPOs have difficulties acquiring the data they need support their modeling efforts. According to a report of the Transportation Research Board (TRB), a part of the National Academies, while federal requirements for modeling have increased, federal funding for model development has been "greatly reduced." 40

One possible option for congressional action would be to provide more federal funding for planning activities, including more funding for model development and data collection. This might be done by increasing the overall funding for transportation programs, or by taking funds from other transportation programs. One possibility would be raising the $1.25 \%$ deduction from highway programs to $1.5 \%$ or more. Some MPOs also argue that providing more flexibility in the use of federal planning funds, particularly those overseen by FHWA, would help them fulfill their planning requirements. Another complaint is that MPOs cannot use all their apportioned federal planning funds because they cannot raise the local matching share due to state and local funding constraints. ${ }^{41}$ An option, therefore, might be to increase the federal share from the current $80 \%$. The downside of this approach is that it may not increase the amount of funds going to metropolitan planning, because raising the federal share might result in less support from state and local government. Another approach might be to increase FHWA and FTA technical support to MPOs by helping with the challenges of modeling including acquiring the necessary data.

A different approach to the issue of MPO funding and technical capacity is to reduce the federal requirements for metropolitan planning. This could be done in a number of different ways. One approach would be to increase the population threshold for the creation of an MPO from 50,000 residents. The STAA, for instance, has proposed increasing the threshold to 100,000 residents, although existing MPOs in areas currently between 50,000 and 100,000 would be maintained as required by current law. The threshold for designating a TMA, with the added requirements for MPOs, might also be increased from the current population of 200,000. Another option might be to drop the requirements for developing long-range plans. Some have suggested that such planning is a waste of time and money because, among other things, conditions 20 years in the future are impossible to predict. ${ }^{42}$ Nevertheless, highways, transit systems, and other significant infrastructure projects typically last much longer than 20 years, so it might be argued that it is worth thinking through as much as possible the longer-term ramifications of such decisions.

\footnotetext{
${ }^{40}$ Transportation Research Board, Metropolitan Travel Forecasting: Current Practice and Future Direction, Special Report 288, Washington, DC, 2007, p. 6, http://onlinepubs.trb.org/onlinepubs/sr/sr288.pdf.

${ }^{41}$ GAO, 2009, p. 17.

${ }^{42}$ Randal O’Toole, 2009.
} 


\section{MPOs and "Livability/Sustainability" Initiatives}

An often heard criticism of federal surface transportation policy is that, over the years, it has largely ignored the effects of transportation investment on urban land use development. Among the transportation policies said to have contributed to these problems are the division of funding into inflexible highway and transit "silos," giving state DOTs almost complete control over the large pot of highway funding, and ignoring the linkages with other federal policy areas such as housing and the environment, particularly at the scale of the metropolitan region. ${ }^{43}$ Consequently, federal support, as previously mentioned, is thought to be biased toward road building in rural and newly urbanizing areas on the urban fringe, which begets more low-density residential and commercial development that is difficult to serve with transit, and, therefore, contributes to more car dependency and motor vehicle emissions.

The remedy, according to this argument, is to focus flexible transportation funding much more on solving problems in metropolitan regions and to leverage the synergies between transportation, housing, and environmental policies. Thus, for instance, federal policies could encourage states and localities to provide for housing, densely formed with commercial development around transit stations and stops. This would, according to its proponents, allow people to choose among a number of ways of traveling - including automobile, transit, bicycling, and walking - to access work, shopping, and other amenities. Such transit-oriented development (TOD) could also provide new customers for transit agencies, reduce vehicle-miles traveled and the associated environmental problems, and lower household transportation expenditures.

Proponents of this approach often include a greater scope for metropolitan transportation planning and greater power for MPOs. The Obama Administration has announced an Interagency Partnership for Sustainable Communities to be entered into by DOT, the Department of Housing and Urban Development (HUD), and the Environmental Protection Agency (EPA). The Partnership is designed "to help improve access to affordable housing, more transportation options, and lower transportation costs while protecting the environment in communities nationwide." " To "enhance integrated planning and investment ... HUD, EPA and DOT propose to make planning grants available to metropolitan areas, and create mechanisms to ensure those plans are carried through to localities. ${ }^{45}$ Presumably, MPOs would be well placed to receive those grants to enhance integrated planning.

From the brief descriptions available, the planning grants announced by the Obama Administration do not appear to be much different than the intent of those available under a program established in TEA-21 and continued in SAFETEA - the Transportation, Community, and System Preservation (TCSP) Program. ${ }^{46}$ As enacted, the TCSP program provides relatively

${ }^{43}$ U.S. Congress, House Committee on Appropriations, Subcommittee on Transportation, Housing and Urban Development, and Related Agencies, Supporting Integrated Planning and Decision Making by Joining-Up Housing and Transportation, Congressional Testimony of Robert Puentes, Brookings Institution, $111^{\text {th }}$ Cong., $1^{\text {st }}$ sess., March 19, 2009, http://www.brookings.edu/ /media/Files/rc/testimonies/2009/0319_transportation_puentes/

0319_transportation_puentes.pdf.

${ }^{44}$ U.S. Department of Transportation, Office of Public Affairs "DOT Secretary Ray LaHood, HUD Secretary Shaun Donovan and EPA Administrator Lisa Jackson Announce Interagency Partnership for Sustainable Communities," Press Release DOT 80-09, June 16, 2009, http://www.dot.gov/affairs/2009/dot8009.htm.

${ }^{45}$ Ibid.

${ }^{46}$ See U.S. Department of Transportation, Federal Highway Administration, "Transportation, Community, and System Preservation Program website," http://www.fhwa.dot.gov/tcsp/index.html. 
small discretionary grants for research and planning to states, MPOs, and local governments to establish "a comprehensive program to address the relationships among transportation, community, and system preservation plans and practices and identify private sector-based initiatives to improve such relationships" (SAFETEA, Section 1117). Although FHWA administers the program in cooperation with other DOT modal administrations and EPA, over the life of the program, TCSP grants in most years have been awarded by congressional designation (earmarks) in appropriations legislation. The exceptions to this were FY1999, FY2000, and FY2007 when some or all of the program's funds were allocated by the Secretary of Transportation. Partly due to the way the program was originally conceived and partly because most of the funds have been earmarked, the TCSP program has generally served as a pot of funding to be used for almost any surface transportation purpose. Without a clear purpose, it is difficult to evaluate the success of the projects being supported and the success of the program as a whole. Similarly, it could be argued that without a clear understanding of what is meant by "sustainability" and "livability," the new planning grants might go for almost any purpose, and the success or failure of funded projects difficult to judge. Congress might also be concerned with the basis on which these new planning grants are to be distributed.

Despite the creation of this Interagency Partnership, moreover, it is not entirely clear without legislation what mechanisms and funding these agencies have at their disposal to follow through with sustainability/livability initiatives. FTA recently announced that it would use unallocated New Starts/Small Starts Program funds (\$130 million) and Bus and Bus-Related Facilities Program funds (\$150 million) to support its livability initiative, but again these program funds are often earmarked by Congress. These relatively modest amounts of funds, moreover, are already designated for transit. ${ }^{47}$ Surface transportation reauthorization, climate change legislation, or both, therefore seem more likely sources of new authority and resources. In the reauthorization of surface transportation programs, one transportation coalition is proposing that metropolitan areas of 1 million or more, with smaller areas given the chance to opt-in, should be required to develop what it calls 20-year Regional Blueprint plans which "demonstrate how proposed transportation investments and system operations and management will coordinate with land use strategies to achieve timely and reasonable progress towards meeting National Transportation Performance Targets." ${ }^{48}$ An aspect of developing the plans is land-use scenario planning. If enacted as proposed, these plans would have to be approved by the state, DOT and EPA, and reviewed by HUD and the Department of Health and Human Services. Once approved, an MPO would be granted federal transportation funds and project selection authority.

\section{Legislative Proposals}

As noted earlier, STAA proposes to provide MPOs with federal funding directly. Moreover, the bill adds some factors that an MPO would be required to consider in the planning process such as enhancing sustainability and livability, reducing GHG emissions and dependence on foreign oil, improving public health, and the relationship between transportation and land use development

\footnotetext{
${ }^{47}$ U.S. Department of Transportation, Federal Transit Administration, "Exempt Discretionary Program Grants (Section 5309) for Urban Circulator Systems,” 74 Federal Register 234, December 8, 2009, pp. 64989-64994, http://edocket.access.gpo.gov/2009/pdf/E9-29245.pdf; U.S. Department of Transportation, Federal Transit Administration, "Section 5309 Bus and Bus Facilities Livability Initiative Program Grants," 74 Federal Register 234, December 8, 2009, pp. 64984-64989, http://edocket.access.gpo.gov/2009/pdf/E9-29242.pdf.

${ }^{48}$ Transportation for America, 2009, p. 24.
} 
patterns. In many cases, STAA would require an MPO to develop performance measures and strategies to meet the targets that are set.

Similar requirements are also included in various versions of climate change legislation that are working their way through Congress. The House passed H.R. 2454 (Waxman/Markey) on June 26, 2009. A Senate version of the legislation, S. 1733, was introduced September 30, 2009. A more limited bill, the Clean, Low Emission, Affordable, New Transportation Efficiency Act (S. 575/H.R. 1329), sometimes referred to as CLEANTEA, that supporters hope might be included in a larger climate change bill proposes some transportation-related aspects of climate change mitigation. Three common characteristics of the bills are a new fund that will receive money from the auction of GHG emission allowances; requirements for states and MPOs responsible for TMAs to develop GHG reduction plans; and the use of funds from the new fund to do the planning and to implement projects in the plan. H.R. 2454 provides $1 \%$ of auctioned funds to be used for transportation purposes, whereas S. 575/H.R. 1329 proposes $10 \%$ of these new funds.

One point of controversy has been whether the GHG emission reduction plans required as part of the planning process must be submitted to and approved by the Environmental Protection Agency instead of or in addition to the Department of Transportation. This provision was included in the version of H.R. 2454 passed by the House Energy and Commerce Committee, but was subsequently dropped in the version passed on the floor of the House. Environmentalists generally favor EPA oversight with the view that this is most likely to result in stricter limits and enforcement. In contrast, the transportation community generally opposes EPA oversight with the view that EPA is likely to favor the environmental over the transportation goals of a plan, and that the added oversight would result in longer approval time for projects. ${ }^{49}$

A different view on livability/sustainability initiatives, and the role that MPOs might play, is that promoting denser, transit-oriented development through more transit funding and planning regulations will result in smaller, less affordable housing and will actually inhibit mobility through increased reliance on transit and more highway congestion. ${ }^{50}$ Trips by transit, analysts propounding this view contend, are almost always slower than those in private vehicles, and transit usage does not typically confer significant environmental benefits. Just as the greatest success in battling urban air pollution has been through technical improvements, particularly the catalytic converter, these analysts argue that reducing GHG emissions will not be done by getting people out of their cars, but by getting them into plug-in hybrids and employing other "green" technologies. ${ }^{51}$ Changing travel behavior, they argue, is an expensive way to reduce GHG emissions and may potentially damage the economy by reducing the efficiency of regional economies.

\footnotetext{
49 Adam Snider and Kate Naseef, "Transportation Stakeholders Fight Proposal To Shift Planning Authority From DOT to EPA," BNA Daily Report for Executives, June 1, 2009, pp. A-10.

${ }^{50}$ Ronald D. Utt, President Obama's New Plan to Decide Where Americans Live and How They Travel, Heritage Foundation, Backgrounder, No. 2260, Washington, DC, April 14, 2009, http://www.heritage.org/Research/ SmartGrowth/upload/bg_2260.pdf; Randal O' Toole, 2009.

${ }^{51}$ Wendell Cox, "Regulating Greenhouse Gases, Not People: Opportunities and Possibilities," Presentation, Heritage Foundation, Washington, DC, July 23, 2009, http://demographia.com/dmgghgher.pdf.
} 


\section{Climate Change Mitigation, Compact Cities, and Transportation}

The arguments for and against more compact urban development and related policies, such as greater transit funding, have taken on new urgency in the past few years because of the concern with GHG emissions and climate change. As a whole, EPA says transportation was responsible for $28 \%$ of all GHG emissions in the United States in 2007. Highway vehicles alone were responsible for $23 \%$ of the U.S. total. ${ }^{52}$ Some analysts have argued that advances in vehicle energy efficiency that reduce fuel consumption and fuel carbon content have been overwhelmed by the growth in vehicle miles traveled. They argue that to reduce the amount of GHG from the transportation sector it will be necessary to reduce vehicle miles traveled (VMT). To do that, one school of thought argues "compact development will reduce the need to drive between 20 and 40 percent, as compared with development at the outer suburban edge with isolated homes, workplaces, and other destinations." 53

A review of the evidence by a special study committee of TRB agreed that denser urban development could reduce VMT. As it noted in the study report:

the literature suggests that doubling residential density across a metropolitan area might lower household VMT by about 5 to 12 percent, and perhaps by as much as 25 percent, if coupled with higher employment concentrations, significant public transit improvements, mixed uses, and other supportive demand management measures. ${ }^{54}$

Even though substantial building of residential and commercial property will presumably take place between now and 2050, doubling residential densities would be very challenging because land use is controlled mostly by local jurisdictions, where existing residents are often very concerned about new development causing congestion, higher property taxes, and the like. Thus:

the committee believes that reductions in VMT, energy use, and $\mathrm{CO}_{2}$ emissions resulting from compact, mixed-use development would be in the range of less than 1 percent to 11 percent by 2050, although the committee disagreed about whether the changes in development patterns and public policies necessary to achieve the high end of these findings are plausible. ${ }^{55}$

\section{Other Issues with Transportation Planning Requirements}

\section{Long-Range Planning}

There are three other issues having to do with transportation planning requirements that Congress may want to consider. The first of these is whether or not MPOs should be required to develop

\footnotetext{
${ }^{52}$ Environmental Protection Agency, Inventory of U.S. Greenhouse Gas Emissions and Sinks: 1990-2007, EPA 430-R09-004, Washington, DC, April 15, 2009, http://www.epa.gov/climatechange/emissions/downloads09/ InventoryUSGhG1990-2007.pdf.

${ }^{53}$ Reid Ewing, Keith Bartholomew, and Steve Winkleman, et al., Growing Cooler: The Evidence on Urban Development and Climate Change (Washington, DC: Urban Land Institute, 2008), p. 9.

${ }^{54}$ Transportation Research Board, Driving and the Built Environment: The Effects of Compact Development on Motorized Travel, Energy Use, and CO2 Emissions, Special Report 298, Washington, DC, 2009, p. 2, http://onlinepubs.trb.org/Onlinepubs/sr/sr298prepub.pdf.

${ }^{55}$ Ibid., p.4.
} 
long-range plans. Critics argue that for two main reasons Congress should not require long-range plans, and should have MPOs focus on the short-term TIP instead. They contend that the metropolitan planning process in most places is flawed because it does not follow a rational planning model where alternative projects are weighed one against another with as many of the benefits and costs measured as possible. Thus, the long-range planning process is dominated by professional planners who often seek to change travel behavior by pursuing smart growth solutions of compact development and by heavily subsidizing non-automobile modes of transportation. The second main reason given for abandoning federal requirements for long-range planning is that it "requires information about the future that is essentially unknowable." includes things like the price of oil, the state of vehicle technology, job and housing location, and the prevalence of telecommuting. Because much of the information necessary for long-term planning is unknowable and because many of the costs and benefits are not quantified, this critique insists that project decisions are typically made on political grounds rather than on rational grounds. Instead, it is argued, metropolitan planning "should focus on the short term, give transportation agencies incentives to improve transportation outcomes, and encourage regions and agencies to rely more on user-fee-based funding mechanisms. ${ }^{, 57}$

\section{Freight Transportation}

A second issue is the incorporation of freight transportation needs and concerns into the planning process. One study has noted that there is no clear mandate for freight planning in federal law, although it is included in Titles 23 and 49 as something that should be considered. ${ }^{58}$ Moreover, the same study also notes that while the planning process is required to include public outreach and participation, in many areas the freight community is not involved in the process in any meaningful way. In places where there is involvement, often through freight advisory committees, the concern is that this is not clearly linked to the development and prioritization of projects. For these reasons, some suggest that freight plans be a required component of statewide and metropolitan transportation plans. Another option is for the federal government to provide extra funds to states and MPOs to hire staff freight experts. ${ }^{59}$

\section{Geographic Scale}

The freight problem is a good example of a third planning issue that could be of concern to Congress, the geographic scale at which planning is undertaken and the integration of metropolitan planning with planning being done at different scales. At the moment, metropolitan transportation plans must be integrated with statewide transportation plans. Because travel, particularly freight, often exceeds the jurisdiction of a single MPO or state, there have been calls for developing a national transportation plan and multi-state freight corridor plans. The National Surface Transportation Policy and Revenue Study Commission, for example, recommended the

\footnotetext{
${ }^{56}$ Randal O’Toole, 2008, p. 22.

${ }^{57}$ Ibid.

${ }^{58}$ Cambridge Systematics, Prime Focus, and Kevin Heanue, Integrating Freight into Transportation Planning and Project-Selection Processes, Transportation Research Board, National Cooperative Highway Research Program, NCHRP Web-Only Document 112, Washington, DC, March 2007, http://onlinepubs.trb.org/onlinepubs/nchrp/ nchrp_w112.pdf.

${ }^{59}$ Freight Stakeholders Association, “Association Stakeholders Call for National Freight Program and Stronger Federal Role,”News Release, May 21, 2009, http://www.intermodal.org/stakeholders_files/documents/

PR_FSC_Call_for_National_Freight_Program.pdf\#page $=3$.
} 
creation of a national strategic plan,$^{60}$ and AASHTO has suggested that Congress provide funding for multi-state corridor planning and investment organizations, such as the I-95 Corridor Coalition. ${ }^{61}$

Heeding these concerns, there have been legislative proposals for adding new transportation planning requirements at the national, state, and regional levels. The STAA, for example, proposes to create new requirements for the development of a National Transportation Strategic Plan, state freight plans, metropolitan mobility plans, and freight corridor plans. The draft bill allows funding to be provided to a maximum of ten freight corridor coalitions to develop the freight corridor plans. A coalition would be comprised of representatives from state DOTs, MPOs, port authorities, freight carriers, and shippers. Under the proposed legislation, the freight corridor plan would be required to be consistent with the long-range statewide transportation plan, the statewide improvement plan, the metropolitan long-range transportation plan, the transportation improvement program, and the metropolitan mobility plan.

Alternatively, it could be argued that requiring these many different layers of planning could consume an enormous amount of effort, time, and thus money, not only on each individual plan but also on coordinating and making the different plans consistent. Moreover, in the case of disagreements it might be difficult to determine which organization and which plan takes precedence. The result, therefore, could be a stalemate that inhibits rather than promotes transportation system improvements.

\section{Conclusion}

Since the end of the Second World War, America has experienced what one historian calls a "metropolitan revolution," in which the economy and culture of tightly drawn regions of urban and suburban development each focused on a central core "was replaced by an amorphous sprawl without a unifying hub or culture." ${ }^{\prime 2}$ According to this view, an important dimension of change has been the increasing fragmentation of metropolitan governance, as urban regions have decentralized over larger and larger areas. For example, the metropolitan area of Pittsburgh, one of the most fragmented, was estimated to have over 400 general-purpose local governments in the late 1990s. Even the Phoenix metropolitan area, one of the least fragmented, was estimated to have 34 local governments. ${ }^{63}$

Despite the amorphousness of contemporary urban development, research suggests that there is a significant interdependence between places in a metropolitan area that bears on a region's economic efficiency and, thus, competitiveness in a national and international context. ${ }^{64}$

\footnotetext{
${ }^{60}$ National Surface Transportation Policy and Revenue Study Commission, Transportation for Tomorrow, Washington, DC, 2007, http://www.transportationfortomorrow.org/final_report/

${ }^{61}$ AASHTO, Freight Authorization Policy, http://www.transportation.org/sites/policy_docs/docs/vi.pdf.

${ }^{62}$ Jon C. Teaford, The Metropolitan Revolution: The Rise of Post-Urban America (New York: Columbia University Press, 2006), p.3.

${ }^{63}$ Myron Orfield, American Metropolitics: The New Suburban Reality (Washington, DC: Brookings Institution Press, 2002), p 132.

${ }^{64}$ Andrew F. Haughwout and Robert P. Inman, "How Should Suburbs Help Their Central Cities? Growth- and Welfare-Enhancing Intrametropolitan Fiscal Distributions," The Annals of the American Academy of Political and Social Science, vol. 626 (November 2009), pp. 39-52.
} 
Governmental fragmentation can make it particularly difficult to deal with problems of a regional nature, such as transportation congestion, that affect metropolitan productivity. This is because, it is argued, "planners and politicians are torn between mitigating the localized effects of regional problems and addressing the common concerns and long-range interests of their larger metropolitan areas." 65

Over the years there have been three main ways that regional governance in metropolitan areas has been enhanced. ${ }^{66}$ The first way is through the state-granted power of annexation by which cities are able to expand into bordering developed or undeveloped unincorporated areas. For example, between 1960 and 1990, Houston added 212 square miles to its jurisdiction, an increase of $65 \%$. A second way of reducing governmental fragmentation is through multijurisdictional consolidation. This is typically done when a city consolidates with a county and the cities within it. An example is the consolidation of the City of Indianapolis and Marion County that took place in 1970. Although there has been some reduction in governmental fragmentation due to annexation of territory and consolidation of local governments, in many states, particularly in the older and more developed Northeast and Midwest, powers to annex and consolidate are weak.

The third main way that regional governance has been enhanced is the development of specialpurpose regional bodies, the most widespread of which are MPOs. Although regional authorities sit uncomfortably in the long established intergovernmental system of federal, state, and local government, strengthened MPOs might offer the most likely current means of reducing the fragmentation of metropolitan governance. This may be a primary reason why some would like to see Congress significantly enhance and broaden the authority and resources of MPOs now and in the future.

\section{Author Contact Information}

William J. Mallett

Specialist in Transportation Policy

wmallett@crs.loc.gov, 7-2216

${ }^{65}$ Ibid., p. 130.

${ }^{66}$ Ibid., pp. 133-140. 